The collection ends with a discussion of the Trans-Pacific Partnership Agreement [TTIP], but unfortunately does not discuss China's non-participation in those negotiations or China's leadership in negotiating potentially rival regional agreements, including the Regional Comprehensive Economic Partnership [RCEP]. Nor does the collection examine in detail China's Foreign Investment Law, which is under revision this year, or its implications for China's BIT regime.

The book makes an important contribution to the recent literature on China's role in the international investment law regime, which includes International Investment Law: A Chinese Perspective by Guiguo Wang (2014) and Chinese Investment Treaties: Policies and Practice by Wenhua Shan and Norah Gallagher (2009). It will be of use to students, academics, and practitioners alike in explaining China's evolving participation in the international investment legal regime and likely future developments.

reviewed by Kate APOSTOLOVA and Lexi MENISH

Freshfields Bruckhaus Deringer

\begin{abstract}
A World Trade Organization for the 2Ist Century: The Asian Perspective edited by Richard BALDWIN, Masahiro KAWAI, and Ganeshan WIGNARAJA. Cheltenham: Edward Elgar Publishing, 2014. 429 pp. Hardcover: $£_{90}$.

doi:IO.IOI $7 / S_{20442513 \text { I } 6000382}$
\end{abstract}

The volume under review is intended for readers who are proficient in international trade law and, in particular, in the law of the World Trade Organization [WTO]. It includes thirteen essays that require a good conceptual understanding of the subject and shed light on, inter alia, the role of the WTO in international trade (Chapters 2-5), protectionism (Chapter 6), the role of regional trade agreements (Chapters 7-IO), the future of the WTO (Chapter I I), the significance of plurilateral trade agreements (Chapter I2), and the feasibility of a multilateral agreement on foreign direct investment (Chapter I3). Importantly, the book presents Asian perspectives on all these issues, with due regard paid to the region's ever-growing weight in the world economy and international trade.

Contributors are professionals and academics from China (the People's Republic and Hong Kong), India, Indonesia, Japan, Singapore—all economic heavyweights in Asia-but also from Australia (Southeast Asia's closest neighbour and economic partner) and Switzerland (where the WTO is headquartered), which enables an external professional vision of international economic processes going on in the region.

The added value of the book is best summarized by the editors in their Introduction:

The world trading system has changed fundamentally over the past years with the expansion of production network and supply-chain trade, adoption of new commercial and industrial policies, and the spread of FTA-led regionalism. These developments are likely to stay but the WTO has not adjusted to cope with them ...

Asia's experience of open trade-led development offers many valuable lessons for other regions. These include the importance of pursuing market-friendly trade and industrial policies to develop supply-chain trade, improving surveillance of non-tariff measures, and consolidating FTAs into a single large region-wide FTA ... (p. Iо)

As the book attempts to combine expert analysis of current developments and challengesincluding of structural difficulties facing the WTO-forecasts, and useful reform proposals, it will be of value to academics and practitioners of international trade law within but also outside Asia. Lessons from ASEAN—one of the most dynamic and successful regional trade organizations in history—could arguably be applicable in such populous and resource-rich regions as Latin America and Africa. In particular, both the European Union, currently experiencing a structural crisis, and the emerging 
Eurasian Economic Union could profit from the creativity and business attitudes of South and Southeast Asian countries. Usefully, contributors' theoretical propositions are supported by reliable statistical data.

Last, but not least, the book's technical features make it quite user-friendly: numerous references to normative and institutional sources and a detailed index should help interested readers to further research issues raised in the volume.

reviewed by Sergey SAYAPIN

KIMEP University

\title{
International Environmental Law
}

\author{
Polar Oceans Governance in an Era of Environmental Change \\ edited by Tim STEPHENS and David L. VANDERZWAAG. \\ Cheltenham/Northampton: Edward Elgar, 20I4. xv + 354 pp. Hardcover: $£_{90}$. \\ doi:IO.IOI7/S204425I316000394
}

The polar regions have experienced significant environmental changes in recent decades. Global warming, ocean acidification, and shifting sea ice pose significant challenges to the unique and fragile marine ecosystems of the Arctic and Antarctica. Moreover, increased human activities, such as fishing, shipping, and tourism threaten the pristine wilderness of the polar regions.

Against this backdrop, an important book on polar oceans governance in an era of environmental change was recently published. The editors, Tim Stephens and David VanderZwaag, are both leading scholars in marine and polar studies. In addition, the publication includes an impressive interdisciplinary array of distinguished scholars from the fields of international law, political science, and geography. This multidisciplinary approach is essential to address polar governance issues.

The book consists of five parts. Part I describes environmental changes in the polar regions; Part II discusses power politics and regime building at the poles; Part III provides a "bipolar" perspective on resource management and environmental protection arising at both poles. Part IV addresses national and foreign policy responses to polar ocean governance challenges. The final part (Part V) on the future of polar ocean governance is the highlight of the book. In this concluding section, Davis's chapter examines the durability of the Antarctic regime, while VanderZwaag reviews how the Arctic Council has advanced the governance agenda.

Though an important contribution to the field, there are a few issues that bear mentioning. First, in the preface, the co-editors mention that "the book assesses how an oceans governance agenda is being advanced in the dynamic ocean regions". I wonder whether this is a research question or the method in which the research agenda is being advanced. If it is the research question, I do not find a detailed answer to this question, other than VanderZwaag's contribution (Chapter I6). Second, according to the title, the book is intended to take a "bipolar" approach, comparing how oceans governance questions are being addressed in both polar regions. It is an excellent book with chapters analyzing pressing concerns in the Arctic and Antarctica, but there is little comparative analysis. Stephens' earlier work acknowledges the limits of Polar comparativism. ${ }^{3}$ Nevertheless, the book would have been strengthened by the inclusion in Part V of a chapter drawing out ways in which the Arctic and Antarctica could learn from each other to better address governance challenges.

reviewed by Nengye LIU

University of Adelaide

3. Tim STEPHENS, “The Arctic and Antarctic Regimes and the Limits of Polar Comparativism" (2OII) 54 German Journal of International Law 3 I 6. 